\title{
Assessment of Some Physico-Chemical Parameters of Lagos Lagoon, Southwestern Nigeria
}

\author{
Peter Olaoye Oyeleke* \\ Department of Science Laboratory Technology, Federal College of Animal Health and Production Technology, PMB 2950, Moor Plantation, \\ Ibadan, Nigeria
}

Samuel Olatunde Popoola

Department of Physical and Chemical Oceanography, Nigerian Institute for Oceanography and Marine Research, PMB 12729, Victoria Island, Lagos, Nigeria

Olushola Ayoola Abiodun

Department of Biological Oceanography, Nigerian Institute for Oceanography and Marine Research, PMB 12729, Victoria Island, Lagos, Nigeria

\begin{abstract}
The pollution status of Lagos Lagoon was investigated to determine some physical and chemical parameters, in order to further understand its water quality. Five locations were selected according to the anthropogenic activities taking place in the areas. The measured parameters are water temperature, salinity, conductivity, $\mathrm{pH}$, dissolved oxygen (DO) and alkalinity. The mean values ranged from $28.50-30.15^{\circ} \mathrm{C}$ for temperature, $7.86-8.50$ for $\mathrm{pH}$, $\mathrm{ND}$ $10.60 \%$ for salinity, $0.18-15.20 \mu \mathrm{S} / \mathrm{cm}$ for electrical conductivity, $12.00-14.00 \mathrm{mg} / \mathrm{l}$ for alkalinity and $1.60-6.40 \mathrm{mg} / \mathrm{l}$ for dissolved oxygen. The statistical analysis of the measured physicochemical parameters revealed non-significant difference $(p>0.05)$ across all stations in the physico-chemical parameters. Generally, the values obtained suggest the influence of anthropogenic activities especially the depletion of DO in most of the stations. Therefore, point source and non-point source pollution into the Lagos Lagoon should be controlled for the health and safety of the aquatic ecosystems. Generally, all the measured parameters were either below or within the permissible limits obtainable in the marine environment.
\end{abstract}

Keywords: Lagos lagoon; Pollution; Physico-chemical parameters; Anthropogenic activities; Aquatic ecosystems.

(4) (i) CC BY: Creative Commons Attribution License 4.0

\section{Introduction}

Pollution of coastal water body has been a serious global challenge in recent time especially in developing nation. Lagos lagoon, (South-Western Nigeria) receive unprecedented waste such as industrial effluents, household sewage, urban and agricultural run offs and municipal waste, which may lead to various changes in the physicochemical characteristics of the marine ecosystem. The physical and chemical characteristics of water constitute an important component of aquatic ecosystem. The waste discharges into marine ecosystem are liable to upset the ecological equilibrium of both living and non-living resources. Therefore, the study on the physico-chemical parameters of water body is very important to evaluate the condition in term of health and productivity of the aquatic ecosystem. It can further bring a thorough knowledge on the environmental and health status of the water mass.

Water quality monitoring has been described as essential tool in fisheries management and in order to safeguard the health of aquaculture system, certain water quality parameters must be monitored [1]. Such parameters among others are $\mathrm{pH}$, temperature, salinity, alkalinity, conductivity and dissolved oxygen. The aforementioned parameters are very crucial to the management of biotic and abiotic resources of the water body especially in a highly industrialized and urbanized area. Therefore, there is need to continuously monitor the physico-chemical parameters of Lagos lagoon to safeguard the improved health status of the aquatic ecosystems. This study aims at assessing some physical and chemical parameters (e.g temperature, $\mathrm{pH}$, salinity, alkalinity, dissolved oxygen) of Lagos lagoon (western Nigeria). Moreover, this study is essential to the establishment of the baseline information for future research and pollution status of the Lagos Lagoon.

\section{Materials and Methods}

\subsection{Description of the Study Area}

The Lagos lagoon is located between longitudes $3^{\circ} 23^{\prime} \mathrm{E}$ and $3^{\circ} 43^{\prime} \mathrm{E}$ and latitudes $6^{\circ} 26^{\prime} \mathrm{N}$ and $6^{\circ} 38^{\prime} \mathrm{N}$, and also the largest among the lagoon system and empties into the Atlantic Ocean at Lagos harbor. The lagoon receives a number of important large rivers namely; Yewa, Ogun, Osun and Ona.

It consists of three main segments namely the Lagos Harbour Segment, the Metropolitan and the Epe Division Segment. It is located in a tropical coastal savannah ecosystem influenced by a bimodal rainfall pattern averaging $700 \mathrm{~mm}$ per annum. Its' hydrology is influenced by surface runoff and inflow from; rivers, several streams, groundwater, over wash of seawater and direct precipitation [2]. 


\section{Sample Collection and Analysis}

Water samples (top/surface water) were collected in plastic containers and DO-bottle for dissolve oxygen determination in six sampling stations (Iddo, Ijora, Apapa, Ibeshe, Okobaba and Egbin) from the Lagos lagoon in May, 2013. The dissolved oxygen was measured by Winkler method, alkalinity by titrimetry, temperature by mercury-in-glass thermometer in-situ while salinity, conductivity and $\mathrm{pH}$ were measured using Multimeter water probe (Horiba U-10 Ltd, Japan). All parameters were measured in laboratory except temperature. The sampling materials and glassware were washed thoroughly and rinsed with distilled water before analysis. All the measurements were carried out in duplicate.

Table-1. Sampling stations and corresponding human activities

\begin{tabular}{l|l|l|l}
\hline Station & Latitude & Longitude & Activities \\
\hline Iddo & $6^{\circ} 27^{\prime} 58.96^{\prime \prime}$ & $3^{\circ} 22^{\prime} 56.45^{\prime \prime}$ & Domestic sewage discharges \\
\hline Ijora & $6^{\circ} 27^{\prime} 41.44^{\prime \prime}$ & $3^{\circ} 22^{\prime} 27.97^{\prime \prime}$ & $\begin{array}{l}\text { Seafood waste, cement bag washing, sewage, } \\
\text { domestic and industrial effluents, oil and } \\
\text { grease }\end{array}$ \\
\hline Apapa & $6^{\circ} 26^{\prime} 43.03^{\prime \prime}$ & $3^{\circ} 22^{\prime} 57.18^{\prime \prime}$ & $\begin{array}{l}\text { Dredging, oil and Grease, spillages, ship } \\
\text { garbage, seaport activities effluents }\end{array}$ \\
\hline Ibeshe & $6^{\circ} 32^{\prime} 58.32^{\prime \prime}$ & $3^{\circ} 28^{\prime} 17.71^{\prime \prime}$ & Dredging \\
\hline Okobaba & $6^{\circ} 28^{\prime} 57.37^{\prime \prime}$ & $3^{\circ} 23^{\prime} 40.98^{\prime \prime}$ & Wood logging, saw dust input \\
\hline Egbin & $6^{\circ} 33^{\prime} 20.96^{\prime \prime}$ & $3^{\circ} 36^{\prime} 19.60^{\prime \prime}$ & Thermal pollution \\
\hline
\end{tabular}

\section{Results and Discussion}

The physico-chemical parameters of Lagos lagoon is shown in Table 1. Temperature ranges from 28.50 to 30.15 ${ }^{\circ} \mathrm{C}$. This agreed with earlier report [3] of 29.00 to $29.60{ }^{\circ} \mathrm{C}$ and Nkwoji, et al. [4] of 26.00 to 31.00 of temperature recorded from Lagos lagoon. It also falls within 27.30 and $30.50{ }^{\circ} \mathrm{C}$ of Lagos lagoon temperature reported by Shelle, et al. [1], 1PUYATE and Rim-Rukeh [5]. It is however slightly lower than 24.00 to $28.33{ }^{\circ} \mathrm{C}$ recorded in Lagos lagoon by Adedayo, et al. [2]. This temperature is expected as normal for Lagos lagoon in a tropical region [6]. Shelle, et al. [1], explained that the pattern of distribution of temperature in the stations is similar in time and space which are influenced by the same meteorological factors couple by tidal flushing. Temperature can alter the amount of oxygen dissolution in water, the rate of photosynthesis by algae and macroscopic plants.

The salinity varied from ND to $10.60 \%$ in the study area. The very low salinity might be attributed to the rainy season (rain-dependent) because of diluting influence of salt precipitations and greatly reduce the salinity [2]. Also the distance of the sampling stations to the ocean contribute to the low salinity recorded in this study.

Conductivity ranged from 0.18 to $17.90 \mu \mathrm{S} / \mathrm{cm}$ in the study area. The conductivity of an aqueous medium is an indication of its ability to conduct an electric current. The low salinity brings about low conductivity. Onyema and Nkwoji [7], has reported conductivity and salinity as associated factors. The lower the dissolve particles or salts, the lower the conductivity of water and vice versa.

The dissolved oxygen of Lagos lagoon water varied between 1.60 to $6.40 \mathrm{mg} / \mathrm{l}$ in the study area Popoola, et al. [8] reported higher DO in Lagos lagoon which was attributed to the agitation of surface water due to channel precipitations, run-offs and discharges during the sampling period. Dissolved oxygen is the amount of gaseous oxygen dissolved in water. It is important parameter in aquatic life as it is required for metabolism aerobic organisms and influences inorganic chemical reactions [6]. The low dissolved oxygen in some stations (except Egbin) might be connected with the heavy pollution load of organic materials from human activities, which have depleted a lot of oxygen. Oxygen can be removed from water surface by respiration of sinking organic matter. Excessive algae and plant growth can also lead to depletion of dissolved oxygen which can be harmful to fish and other aquatic ecosystems in the river [9]. The dissolved oxygen at Egbin station $(6.40 \mathrm{mg} / \mathrm{l})$ is very adequate for aquatic life.

Table-2. Physico-chemical parameters of water samples collected from Lagos lagoon

\begin{tabular}{l|l|l|l|l|l|l}
\hline Station & $\begin{array}{l}\text { Temperature } \\
\left({ }^{\circ} \mathbf{C}\right)\end{array}$ & $\begin{array}{l}\text { Salinity } \\
(\mathbf{\% o})\end{array}$ & $\begin{array}{l}\text { Conductivity } \\
(\boldsymbol{\mu S / c m})\end{array}$ & $\mathbf{p H}$ & $\begin{array}{l}\text { Alkalinity } \\
(\mathbf{m g} / \mathbf{l})\end{array}$ & $\begin{array}{l}\text { Dissolved Oxygen } \\
(\mathbf{m g} / \mathbf{l})\end{array}$ \\
\hline Iddo & 29.00 & 8.80 & 15.20 & 8.51 & 14.00 & 3.20 \\
\hline Ijora & 29.50 & 8.50 & 14.70 & 8.11 & 14.00 & 2.40 \\
\hline Apapa & 29.40 & 10.60 & 17.90 & 8.15 & 12.00 & 2.40 \\
\hline Ibeshe & 29.50 & 1.50 & 2.99 & 8.26 & 12.00 & 2.40 \\
\hline Okobaba & 30.15 & 7.10 & 12.40 & 8.13 & 12.00 & 1.60 \\
\hline Egbin & 28.50 & ND & 0.18 & 7.86 & 14.00 & 6.40 \\
\hline
\end{tabular}

ND $=$ Not Detected

The dissolved oxygen level in water increases as the temperature of the water decreases or as the pressure in the water increases [10].

The $\mathrm{pH}$ values of the water ranged from 7.86 to 8.11 in the study area. These values indicate that the study areas of lagoon are alkaline which is in agreement with values for tropical marine water and other similar studies [1, $3-5,7,8,11]$. The water $\mathrm{pH}$ provides insight into its hydrogen ion activity and used widely as indicator of the 
alkalinity and acidity of a medium [6]. $\mathrm{pH}$ is critical in the aquatic ecosystem because it affects the functions of virtually all enzymes, hormones, and other proteins of the body that control metabolism.

Alkalinity in the study area ranged between 12.00 and $14.00 \mathrm{mg} / \mathrm{l}$. The alkalinity was low across the sampling stations indicating low buffering capacity of the water. The quality of water in different phases of natural aquatic system is reflected by the level of alkalinity, hardness, free carbon dioxide and other physical and chemical parameters [9].

\section{Conclusion}

This study had shown the influence of anthropogenic activities in the sampling stations, which can further be detrimental to the aquatic ecosystems. Uncontrolled discharge of untreated wastewater, sewage, urban runoffs, domestic and industrial effluent into the lagoon has seriously degraded the quality of the water (Table 2). This can create serious health risks to the general populace. We hereby suggest rigorous enlightenment on the safer attitudes toward the reduction of pollution in marine environment. Continuous monitoring of the health status of the Lagos lagoon should also be encouraged to be abreast of the health status of the Lagoon systems.

\section{References}

[1] Shelle, R. O. D., Adeleye, A. O., and Ladigbolu, I. A., 2010. "Water quality monitoring, a must in fisheries and aquaculture management." World Rural Observations, vol. 2, pp. 38-41

[2] Adedayo, A., Adeyemi, D., Uyimandu, J. P., Chigome, S., and Anyakora, C., 2012. "Evaluation of the levels of polycyclic aromatic hydrocarbons in surface and bottom waters of lagos lagoon, Nigeria." African Journal of Pharmaceutical Sciences and Pharmacy, vol. 3, p. 1.

[3] Eruola, A. O., Ufoegbune, Ufoegbune, G. C., Ojekunle, Z. O., Makinde, A. A., and Ogunyemi, I. O., 2011. "Analytical investigation of pollutants in lagos coastal waters, Nigeria." Advances in Analytical Chemistry, vol. 1, pp. 8-11.

[4] Nkwoji, J. A., Yakub, A., Ajani, G. E., Balogun, K. J., Renner, K. O., Igbo, J. K., Ariyo, A. A., and Bello, B. O., 2010. "Seasonal variations in the water chemistry and benthic macroinvertebrates of a south western lagoon, lagos, Nigeria." Journal of American Science, vol. 6, Available: https://www.sciencepub.net/american/am0603/12_2084_joseph_am0603_85 92.pdf

[5] 1PUYATE, Y. T. and Rim-Rukeh, A., 2008. "Variability with depth of some physico-chemical and biological parameters of Atlantic Ocean water in part of the coastal area of Nigeria." J. Appl. Sci. Environ. Manage, vol. 12, pp. 87-91.

[6] Oketola, A. A., Adekolurejo, S. M., and Osibanjo, O., 2013. "Water quality assessment of river ogun using multivariate statistical techniques." Journal of Environmental Protection, vol. 4, pp. 466-479 Available: http://dx.doi.org/10.4236/jep.2013.45055

[7] Onyema, I. C. and Nkwoji, J. A., 2009. "The water chemistry and plankton dynamics of a tropical high energy erosion beach in lagos." Journal of American Science, vol. 5, Available: http://www.jofamericanscience.org/journals/amsci/am0601/15 1091_WATER_CHEMISTRY am0601.pdf

[8] Popoola, S. O., Udochu, U., Adekunbi, F. O., Nwoko, C. J., and Fashade, A. O., 2015. "Spatial variations in the physicochemical parameters of some selected locations in Lagos lagoon, Southwestern Nigeria." Journal of $\quad$ Science, $\quad$ vol. $\quad$ Available: https://www.researchgate.net/publication/284283956_SPATIAL_VARIATIONS_IN_THE_PHYSICOCHE MICAL_PARAMETERS_OF_SOME_SELECTED_LOCATIONS_IN_LAGOS_LAGOON_SOUTHWES TERN_NIGERIA

[9] Hach, R. L. C. C., Klein, J., and Gibbs, C. R., 1992. Introduction to biochemical oxygen demand (technical information series - booklet 7), hach technical center for applied analytical chemistry. Loveland, Colorado, USA: Hach Company.

[10] Keily, G., 1998. Environmental engineering. London: McGraw-Hill International Limited.

[11] Akinde, S. B. and Obire, O., 2011. "In-situ physico-chemical properties of the deep atlantic ocean water column and their implications on heterotrophic bacterial distribution in the gulf of guinea." Advances in Applied Science Research, vol. 2, pp. 470-482. 